\title{
Multiple mechanisms underlying acquired resistance to taxanes in selected docetaxel- resistant MCF-7 breast cancer cells
}

Harris Wang ${ }^{1}$, The Vo ${ }^{1}$, Ali Hajar ${ }^{1}$, Sarah Li ${ }^{1}$, Xinmei Chen ${ }^{1}$, Amadeo M Parissenti ${ }^{3}$, David N Brindley ${ }^{2}$ and Zhixiang Wang ${ }^{1 *}$

\begin{abstract}
Background: Chemoresistance is a major factor involved in a poor response and reduced overall survival in patients with advanced breast cancer. Although extensive studies have been carried out to understand the mechanisms of chemoresistance, many questions remain unanswered.

Methods: In this research, we used two isogenic MCF-7 breast cancer cell lines selected for resistance to doxorubicin (MCF-7 DOX $_{\text {) }}$ or docetaxel (MCF-7 TXT $_{\text {T }}$ ) and the wild type parental cell line (MCF-7 $\mathrm{CC}$ ) to study mechanisms underlying

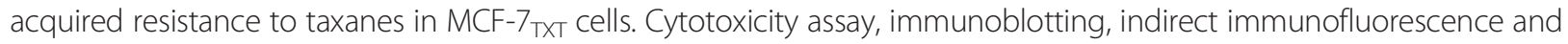
live imaging were used to study the drug resistance, the expression levels of drug transporters and various tubulin isoforms, apoptosis, microtubule formation, and microtubule dynamics.
\end{abstract}

Results: MCF-7 $7_{\text {TXT }}$ cells were cross resistant to paclitaxel, but not to doxorubicin. MCF-7 Dox cells were not cross-resistant to taxanes. We also showed that multiple mechanisms are involved in the resistance to taxanes in MCF-7 TXT cells. Firstly, MCF-7 ${ }_{\text {TXT }}$ cells express higher level of ABCB1. Secondly, the microtubule dynamics of MCF-7 $7_{\text {TXT }}$ cells are weak and insensitive to the docetaxel treatment, which may partially explain why docetaxel is less effective in inducing M-phase arrest and apoptosis in MCF-7 7 TT cells in comparison with MCF-7 CC $_{\text {cells. Moreover, MCF-7 }}$ XX cells express relatively higher levels of $\beta 2$ - and $\beta 4$-tubulin and relatively lower levels of $\beta 3$-tubulin than both MCF-7 ${ }_{C C}$ and MCF-7 $7_{\text {DOx }}$ cells. The subcellular localization of various $\beta$-tubulin isoforms in MCF-7 $7_{\text {TXT }}$ cells is also different from that in MCF-7 ${ }_{C C}$ and MCF-7DOx cells.

Conclusion: Multiple mechanisms are involved in the resistance to taxanes in MCF-7 $7_{\text {TXT }}$ cells. The high expression level of $A B C B 1$, the specific composition and localization of $\beta$-tubulin isoforms, the weak microtubule dynamics and its insensitivity to docetaxel may all contribute to the acquired resistance of MCF-7 $7_{\text {TXT }}$ cells to taxanes.

Keywords: Breast cancer, Taxane, Doxorubicin, Chemoresistance, MCF-7 cell, ABC proteins, $\beta$-tubulin isoforms, Microtubule dynamics

\section{Background}

Breast cancer is the most common type of cancer in women and accounts for one third of all cancers in women. The incidence of breast cancer is continuously increasing, with more than one million reported new cases diagnosed per year worldwide [1-3]. Among these cases, 20-30\% present with metastatic or locally advanced disease,

\footnotetext{
* Correspondence: zhixiang.wang@ualberta.ca

${ }^{1}$ Department of Medical Genetics, University of Alberta, Edmonton, AB T6G $2 \mathrm{H} 7$, Canada

Full list of author information is available at the end of the article
}

and another 30\% will develop recurrent or metastatic disease [3].

Chemotherapy is often used to treat breast cancer in both the adjuvant and neoadjuvant settings and often involves the administration of anthracyclines together with (or followed by) taxanes. Typical taxanes used in current treatment regimens for breast cancer include paclitaxel (Taxol) and docetaxel (Taxotere), while typical anthracyclines include doxorubicin (Adriamycin) and epirubicin (Pharmorubicin) [4,5]. Docetaxel belongs to the group of taxanes that were first introduced into clinical use during 
the 1990's. Both paclitaxel and docetaxel bind to $\beta$-tubulin in assembled tubulin, thereby reducing depolymerisation [6]. Taxanes stabilise microtubules and dampens microtubule dynamics to prevent the normal formation of mitotic spindles [6]. This leads to chronic activation of the spindle assembly checkpoint (SAC), which in turn leads to mitotic arrest [7]. Extended mitotic arrest eventually leads to cell death [8]. We have recently shown that the taxanes also strongly induce TNF alpha production, which may also promote apoptosis through binding to its receptor TNFR1 [9]. On the other hand, doxorubicin is an anthracycline antibiotic, which intercalates with DNA. While the mechanisms of action are not yet completely understood, one very important component of the activity of doxorubicin is its interaction with chromatin and its constitutive components: DNA and histones. These interactions lead to chromatin unfolding and aggregation. This chromatin structural disruption is likely to interfere with DNA replication and transcription, which eventually leads to cell apoptosis. It was also suggested that doxorubicin interacts with key cellular enzymes such as topoisomerases I and II. Topoisomerase II mediated DNA damage by doxorubicin is followed by G1 and G2 growth arrest and induction of apoptosis, which correlates with tumor response and patient outcomes [1,10-12].

Resistance to chemotherapy can occur prior to drug treatment (primary or innate resistance) or develop over time following exposure to a given chemotherapeutic agent (acquired resistance) [13]. Chemoresistance presents a major obstacle to therapy and leaves few effective treatment options [5]. Both innate and acquired resistance to taxanes and doxorubicin are common as more breast cancer patients receive these drugs [1,14]. The most established in vitro mechanism for resistance to more than one chemically unrelated class of agents (multidrug resistance) is the overexpression of drug efflux proteins. The best known drug efflux proteins are members of the ATP-binding cassette $(\mathrm{ABC})$ superfamily, including P-glycoprotein [Pgp; also called multidrug resistance protein $(\mathrm{MDR})$ or $\mathrm{ABCB} 1]$, the multidrug resistanceassociated protein 1 [MRP-1, also called ABCC1], and the breast cancer resistance protein [BCRP, also called ABCG2]. ABC transporter substrates include a diverse array of compounds, many of them structurally unrelated. These proteins protect cells and tissues by exporting potential toxins, including anticancer agents from cells in normal tissues and cancer cells [4]. In general, ABCB1 transports large hydrophobic compounds, whereas ABCC1 and ABCG2 transport both hydrophobic drugs and large anionic compounds [15]. ABC proteins have been implicated in both taxane and doxorubicin resistance in breast cancers $[1,3,4,14]$. When 60 cell lines were tested, it was found that the lower the ABCB1 expression level, the greater the sensitivity to paclitaxel in the cell lines [16].
However, in clinic studies the results are controversial. One study shows that increased ABCB1 expression level is correlated with shortened disease-free survival [17]. Some other studies show that no correlation between $\mathrm{ABCB}$ expression level and response to either paclitaxel or docetaxel treatment in breast cancer patients [18]. On the other hand, both $\mathrm{ABCC} 1$ and $\mathrm{ABCG} 2$ mediate resistance to doxorubicin, but not paclitaxel $[5,19]$.

Resistance may also arise from the expression of proteins underlying a specific drug's mechanism of action. For example, taxanes operate by binding to $\beta$-tubulin. Taxane-resistant cancer cells may have altered expression and function of certain $\beta$-tubulin isotypes, caused by mutations in $\beta$-tubulin, and increased microtubule dynamics associated with altered microtubule-associated protein (MAP) expression [3,4,14,20-23]. Altered expression of the topoisomerase IIa gene (TOP2A), which encodes the enzyme target of the anthracyclines, may confer anthracycline resistance [24].

Chemoresistance is a major factor involved in poor response and reduced overall survival in patients with locally advanced and metastatic breast cancer. Chemoresistance is a very challenging and complex phenomenon involving a number of complex mechanisms. Elucidating these mechanisms is crucial to understanding how to improve the use of taxane and doxorubicin in cancer treatment. Although extensive studies have been carried out to understand chemoresistance in breast cancer both in vitro and clinically, many questions remain unanswered. In previous research, we established several drug-resistant MCF-7 cell lines by exposing MCF-7 cells to increasing concentrations of specific chemotherapy drugs [25]. Our study showed that while drug transporters were induced during selection for drug resistance (which reduced drug accumulation into tumour cells), additional drug-transporter-independent mechanisms must play important roles [25]. In the current study, we used two of our preciously created resistant cell lines, doxorubicin-resistant MCF-7 cells (MCF-7 DOX $_{\text {) }}$ and docetaxel-resistant MCF-7 cells (MCF-7 ${ }_{\text {TXT }}$ ), to study the mechanisms underlying the acquired drug resistance, with emphasis on the resistance to taxanes in MCF-7 $7_{\text {TXT }}$ cells. We show that MCF-7 $7_{\text {TXT }}$ cells are ten times more resistant to both docetaxel and paclitaxel than the sensitive wild type parental cell line $\left(\mathrm{MCF}-7_{\mathrm{CC}}\right)$. MCF- $7_{\mathrm{DOx}}$ cells are eight times more resistant to doxorubicin than $\mathrm{MCF}-7_{\mathrm{CC}}$ cells. However, MCF-7 ${ }_{\text {TXT }}$ cells are not cross-resistant to doxorubicin and MCF-7 $7_{\text {DOX }}$ cells are not cross-resistant to taxanes. We also showed that multiple mechanisms are involved in the resistance to taxanes in MCF- $7_{\text {TXT }}$ cells. Firstly, the selected chemo-resistant cell lines express higher levels of certain $\mathrm{ABC}$ proteins. The expression level of $\mathrm{ABCB} 1$ is very high only in the MCF- $7_{\mathrm{TXT}}$ cells and the expression level of $\mathrm{ABCC} 1$ is very high only in the MCF-7 $7_{\mathrm{DOx}}$ cells. 
The expression level of ABCG2 is similar in both the selected chemo-resistant and the parental MCF-7 cell lines. Moreover, MCF-7 ${ }_{\text {TXT }}$ cells are also more resistant to taxane-induced mitotic spindle disruption and $M$ phase arrest, which leads to apoptosis. The microtubule dynamics of MCF- $7_{\text {TXT }}$ cells are insensitive to the docetaxel treatment, which may partially explain why docetaxel is less effective in inducing $\mathrm{M}$-phase arrest and apoptosis in MCF- $7_{\text {TXT }}$ cells in comparison with $\mathrm{MCF}-7_{\mathrm{CC}}$ cells. Finally, MCF-7 $7_{\text {TXT }}$ cells express relatively higher levels of $\beta-2$ and $\beta-4$ tubulin and relatively lower levels of $\beta-3$ tubulin than both $\mathrm{MCF}-7_{\mathrm{CC}}$ and MCF-7 $\mathrm{DOX}$ cells. The subcellular localization of various $\beta$-tubulin isoforms in MCF- $7_{\text {TXT }}$ cells is also different from that in $\mathrm{MCF}-7_{\mathrm{CC}}$ and MCF-7 1 DOX cells.

\section{Methods}

\section{Cell culture and treatment}

The cell lines that were used in this study include MCF-7 breast cancer cells selected for resistance to doxorubicin $\left(\mathrm{MCF}-7_{\mathrm{DOX}}\right)$ and docetaxel $\left(\mathrm{MCF}-7_{\mathrm{TXT}}\right)$, and the non-resitant wild type parental cell line $\left(\mathrm{MCF}-7_{\mathrm{CC}}\right)$ as we previously described (Hembruff [25]). Detailed selection process and characterization of these selected cell lines were described previously [25]. All cells were grown at $37^{\circ} \mathrm{C}$ in Dulbecco's modified Eagle's medium containing $10 \%$ FBS supplemented with non-essential amino acids and were maintained in a $5 \% \mathrm{CO}_{2}$ atmosphere. MCF-7 7 ox cells were maintained at $95 \mathrm{nM}$ doxorubicin and MCF- $7_{\text {TXT }}$ cells were maintained at $5 \mathrm{nM}$ docetaxel.

\section{Antibody and chemicals}

Mouse monoclonal anti-ABCG2 (BXP-21), rabbit polyclonal anti-MDR (ABCB1) (H-241), and rabbit polyclonal anti-MRP1 (ABCC1) (E-19) antibodies were purchased from Santa Cruz Biotechnology, Inc. (Santa Cruz, CA). Rabbit anti-tubulin $\beta 1$ and $\beta 3$, and mouse monoclonal anti-tubulin $\beta 2$ and $\beta 4$ antibodies were purchased from Abcam (Toronto, ON). All secondary antibodies conjugated with FITC and TRITC were from Life Technologies Inc (Burlington, ON). Mammalian Protein Extraction Reagent (M-Per) was purchased from Thermo Fisher Scientific Inc. (Rockford, IL USA). Vybrant MTT Cell Proliferation Assay Kit and GFP tagged $\alpha$-tubulin with the CellLight $^{\odot}$ Reagents BacMam 2.0 were from Invitrogen (Grand Island, NY). Unless otherwise specified, all chemicals were purchased from Sigma-Aldrich.

\section{Cytotoxicity assay}

Cells were plated onto 96-well plates, 10,000 cell/well for each MCF-7 cell line. Forty-eight hours later, the culture medium was replaced by fresh medium containing various concentrations of Doxorubicin, paclitaxel and docetaxel for $24 \mathrm{~h}$. The percentages of viable cells were then determined by the conversion of the water soluble MTT (3-(4,5-dimethylthiazol-2yl)-2,5-diphenyltetrazolium bromide) to an insoluble formazan, relative to drug free controls, using the Vybrant MTT Cell Proliferation Assay Kit (Invitrogen, Grand Island, NY). All cytotoxicity data shown are the means of at least three independent experiments. Similar experiment were performed with drug treatment for $72 \mathrm{~h}$.

\section{Immunoblotting}

The expression levels of various proteins were examined by immunoblotting as previously described [26]. Briefly, protein lysates from three MCF-7 cell lines treated or not treated with docetaxel were obtained by lysing cells with M-PER Mammalian Protein Extraction Reagent and a protease inhibitor cocktail. The expression of various proteins including $\mathrm{ABCB} 1, \mathrm{ABCC} 1, \mathrm{ABCG} 2, \beta 1-, \beta 2-, \beta 3-$, and $\beta 4$-tubulin was examined by immunoblotting following SDS PAGE.

\section{Apoptosis assay}

Cell apoptosis was determined by chromatin condensation and nuclear morphology. Cells in cover slips were treated with various concentrations of drugs for $24 \mathrm{~h}$. DNA was stained by DAPI (300 $\mathrm{nM})$ for $5 \mathrm{~min}$. Chromatin condensation and nuclear morphology were examined using a Delta Vision microscopic system. Delta Vision SoftWoRx software was used to deconvolve the images.

\section{Indirect immunofluorescence}

Indirect immunofluorescence was carried out as previously described [26]. For the staining of ABC proteins, cells were either treated or not treated with docetaxel at indicated concentrations for $24 \mathrm{~h}$. After fixation with $-20^{\circ} \mathrm{C}$ methanol, cells were incubated with antibodies against ABCB1, $\mathrm{ABCC} 1$ or $\mathrm{ABCG} 2$, followed by FITC-conjugated secondary antibodies. Nuclei were then count stained with DAPI. For the expression and localization of $\alpha$-tubulin and various $\beta$-tubulin isoforms including $\beta 1, \beta 2, \beta 3$, and $\beta 4$, cells were incubated with the antibodies against these tubulins followed by incubation with TRITC-conjugated secondary antibodies. The images were obtained using a Delta Vision microscopic system. Delta Vision SoftWoRx software was used to deconvolve the images.

\section{Live imaging}

Live imaging was used to study docetaxel induced M-phase arrest and microtubule dynamics. As previously described [26], MCF-7 ${ }_{\mathrm{CC}}$ and MCF-7 ${ }_{\mathrm{TXT}}$ cells were cultured on $35 \mathrm{~mm}$ poly-L-lysine-coated coverslips (Fisher) overnight. To assay docetaxel-induced M-phase arrest, cells were incubated with DMEM containing 
$250 \mathrm{ng} / \mathrm{ml}$ Hoechst 33342 (Calbiochem) for $10 \mathrm{~min}$ to stain DNA. Then, the coverslip was mounted on a sample holder and incubated with DMEM without phenol red, supplemented with $10 \%$ FBS with or without docetaxel. To assay microtubule dynamics, the cells were transfected with GFP tagged $\alpha$-tubulin with the CellLight ${ }^{\oplus}$ Reagents BacMam 2.0 (Invitrogen, Grand Island, NY) for $24 \mathrm{~h}$ according to the Manufacturer's instruction. The coverslip was then mounted on a sample holder and incubated with DMEM without phenol red, supplemented with 10\% FBS either with or without docetaxel of indicated concentrations for $1 \mathrm{~h}$.

Experiments were performed in a chamber maintained at $37^{\circ} \mathrm{C}$ and $5 \% \mathrm{CO} 2$. The fluorescence images were acquired at various time intervals for indicated time using a Delta Vision microscopic system. Delta Vision SoftWoRx software was used to deconvolve images and generate movies. To calculate the extension and shortening rate of the microtubules, we followed the microtubules that were either growing or shrinking. For each datum, at least 20 microtubules from 8 cells were measured.

\section{Results}

Cross-resistance of MCF-7 $7_{\mathrm{CC}}, \mathrm{MCF}_{\mathrm{D}} \mathrm{7}_{\mathrm{DOX}}$, and MCF-7 $7_{\mathrm{TXT}}$ cells to various cancer drugs

We first determined whether the selected drug resistant cell lines show cross-resistance to different drugs. The three cell lines used in the experiments include Docetaxel-resistant MCF-7 cells selected with increased docetaxel concentration (MCF-7 ${ }_{\mathrm{TXT}}$ ), Doxorubicin-resistant MCF-7 cells selected with increased doxorubicin concentration (MCF-7 ${ }_{\text {DOX }}$ ), and the parent non-resistant MCF-7 cell line $\left(\mathrm{MCF}-7_{\mathrm{CC}}\right)$ [25]. The sensitivity of $\mathrm{MCF}-7_{\mathrm{CC}}$, MCF-7 $7_{\text {TXT }}$ and MCF-7 1 DOX cells to various drugs was determined by using a cytotoxicity assay based on the Vybrant MTT Cell Proliferation Assay following drug treatment for $24 \mathrm{~h}$ (Figure 1) or $72 \mathrm{~h}$ (data not shown). The patterns were similar for both 24 and $72 \mathrm{~h}$ drug treatment, but $72 \mathrm{~h}$ treatment shifted the curve downward. Based on the dose-response curve from this cytotoxicity assay, the $\mathrm{IC}_{50} \mathrm{~s}$ for various drugs were calculated for the above cell lines (Table 1). As shown in Table 1, MCF-7 DOX cells were nearly 8 times more resistance to Doxorubicin than $\mathrm{MCF}-7_{\mathrm{CC}}$ cells; however, MCF-7 $\mathrm{DOX}$ cells showed no resistance to paclitaxel and docetaxel. In fact MCF-7 DOx cells are slightly more sensitive to paclitaxel and docetaxel than MCF- $7_{\mathrm{CC}}$ cells. Similarly, MCF- $7_{\text {TXT }}$ cells were 10 times more resistant to paclitaxel and docetaxel than $\mathrm{MCF}-7_{\mathrm{CC}}$ cell, but showed no resistance to Doxorubicin. These data indicate that docetaxelresistant MCF-7 ${ }_{\text {TXT }}$ cells are cross-resistant to paclitaxel. However, MCF- $7_{\text {TXT }}$ and MCF- $7_{\text {DOX }}$ cells show no crossresistance to doxorubicin and taxanes, respectively.

\section{Expression and subcellular localization of $A B C$ proteins}

The most established in vitro mechanism for resistance to more than one chemically unrelated class of agents is the overexpression of drug efflux proteins such as ABC proteins. We previously examined the mRNA levels of several ABC proteins in these MCF-7 cell lines [25]. Here we quantitatively determined the expression level and localization of several $A B C$ superfamily proteins including $\mathrm{ABCB} 1, \mathrm{ABCC} 1$ and $\mathrm{ABCG} 2$ by immunoblotting and immuofluorescence. These three $A B C$ proteins were chosen because they are most studied clinically and are very important in breast cancer [19].

The expression levels of ABCB1, ABCC1 and ABCG2 were first examined by immunoblotting and quantified by densitometry. As shown in Figure $2 A \& B$, the expression level of ABCB1 was much higher in MCF-7 ${ }_{\text {TXT }}$ cells than that in MCF-7 $\mathrm{CC}$ and MCF-7 ${ }_{\text {DOx }}$ cells. The expression level of $A B C C 1$ was much higher in $M C F-7_{D O X}$ cells than that in MCF-7 ${ }_{\mathrm{CC}}$ and MCF-7 ${ }_{\text {TXT }}$ cells. ABCG2 level was similar in all three cell lines, but slightly higher in MCF-7 DOX cells. These findings are consistent with our previous data [25].

The expression level and the localization of ABCB1, $\mathrm{ABCC} 1$ and $\mathrm{ABCG} 2$ were further examined by immunofluorescence. As in Figure $2 \mathrm{C}, \mathrm{ABCB} 1, \mathrm{ABCC} 1$ and ABCG2 are all significantly localized to the plasma membrane with weak intracellular stain, consistent with their roles in drug efflux. Consistent with our immunoblotting data, MCF-7 ${ }_{\text {TXT }}$ cells showed much stronger stain of $\mathrm{ABCB} 1$ than $\mathrm{MCF}-7_{\mathrm{CC}}$ and $\mathrm{MCF}-7_{\mathrm{DOX}}$ cells. MCF-7 DOx cells showed much stronger stain of ABCC1 than $\mathrm{MCF}-7_{\mathrm{CC}}$ and $\mathrm{MCF}-7_{\mathrm{TXT}}$ cells. The ABCG2 stain was similar in all three cell lines. These results suggest that different $\mathrm{ABC}$ proteins may confer resistance to different drugs.

\section{The effects of docetaxel treatment on the expression and subcellular localization of $A B C$ superfamily proteins}

We next examined whether treatment of these three cell line with docetaxel changes the expression level or subcellular localization of $\mathrm{ABCB} 1, \mathrm{ABCC} 1$ and $\mathrm{ABCG} 2$ by using the same method described above. MCF- $7_{\mathrm{CC}}, \mathrm{MCF}-7_{\mathrm{TXT}}$ and MCF-7 DOx cells were treated with docetaxel of indicated concentrations for $24 \mathrm{~h}$. Western blotting showed that the expression level of ABCB1, ABCC1 and ABCG2 was little changed following the treatment (Figure $3 \mathrm{~A}$ ). Indirect immunofluorescence further showed that there was no significant change in the expression level of $\mathrm{ABCB} 1, \mathrm{ABCC} 1$ and $\mathrm{ABCG} 2$ (Figure $3 \mathrm{~B}$ ). The localization of $\mathrm{ABCB} 1, \mathrm{ABCC} 1$ and $\mathrm{ABCG} 2$ was still exclusively at the plasma membrane following docetaxel treatment (Figure 3B). We observed a stronger stain in cells arrested in $\mathrm{M}$ phase following docetaxel treatment. This stronger plasma membrane stain of $\mathrm{ABCB} 1, \mathrm{ABCC} 1$ and $\mathrm{ABCG} 2$ 

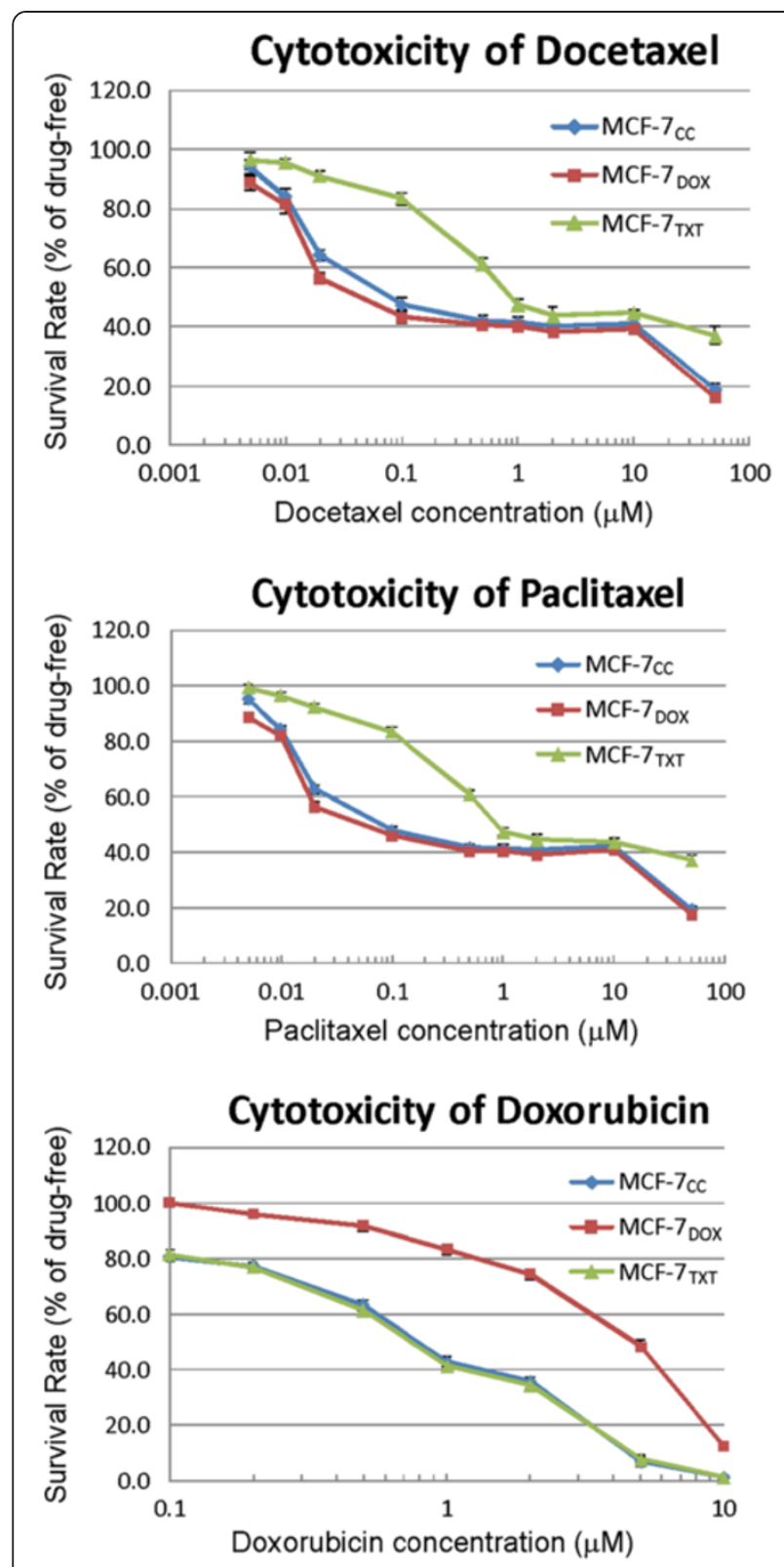

Figure 1 Dose-response curve to drug treatment. Cytotoxicity of paclitaxel, docetaxel and doxorubicin at various concentrations for MCF-7 $7_{C C}$ MCF-7 $7_{T X T}$ and MCF-7 ${ }_{\text {Dox }}$ Cells was determined following $24 \mathrm{~h}$ drug treatment as described in Methods. The means of at least three independent experiments are plotted. The error bar is the standard error; most of them are smaller than the symbols of the plot.

may be due to the relatively smaller size and the roundness of the cells in $M$ phase.

The effects of cancer drugs on apoptosis and microtubule formation

After examining the relationship between the acquired drug resistance in $\mathrm{MCF}-7_{\mathrm{TXT}} / \mathrm{MCF}-7_{\mathrm{DOx}}$ cells and the expression level of $\mathrm{ABC}$ proteins, we next explored the
Table 1 IC50 (mM) of paclitaxel, docetaxel and doxorubicin for MCF-7wt, MCF-7txt and MCF-7dox cells (calculated from Figure 1)

\begin{tabular}{lccc}
\hline & Docetaxel & Paclitaxel & Doxorubicin \\
\hline MCF-7wt & 0.08 & 0.07 & 0.8 \\
MCF-7txt & 0.9 & 0.8 & 0.8 \\
MCF-7dox & 0.04 & 0.04 & 5 \\
\hline
\end{tabular}

involvement of other possible mechanisms. It is well documented that taxanes kill cells by stabilizing their microtubules, which eventually causes cellular apoptosis. We, therefore, examined the effects of paclitaxel, docetaxel and doxorubicin on microtubule formation and cell apoptosis in these cells.

Microtubule formation and the cell apoptosis were examined by fluorescence microscopy (Figure 4). Microtubule formation was assayed by the tubulin stain (red). Cell apoptosis was determined by the nuclear condensation revealed by DAPI stain (blue) (Figure 4A\&B). Cell apoptosis was quantitated by calculating the percentage of apoptotic cells at each given drug concentration (Figure 4C-D). Both paclitaxel and docetaxel induced much stronger cell apoptosis in $\mathrm{MCF}-7_{\mathrm{CC}}$ and $\mathrm{MCF}-7_{\mathrm{DOx}}$ cell than that in MCF-7 ${ }_{\mathrm{TXT}}$ cells at a drug concentration lower than $2 \mu \mathrm{M}$ (Figure 4). At $10 \mathrm{nM}$, paclitaxel and docetaxel began to induce apoptosis in $\mathrm{MCF}-7_{\mathrm{CC}}$ and MCF-7 $7_{\text {DOX }}$ cells (10\%), but a similar level of apoptosis in MCF-7 TXT $_{\text {cell only occurs when paclitaxel and docetaxel }}$ reach a concentration of $100 \mathrm{nM}$. The maximum apoptosis (approximately 60\%) in MCF-7 $\mathrm{CC}$ and MCF-7 $\mathrm{DOX}$ cells was induced by paclitaxel and docetaxel at a concentration of $500 \mathrm{nM}$. Meanwhile, a similar level of apoptosis in MCF-7 ${ }_{\text {TXT }}$ cell was induced by paclitaxel and docetaxel at a concentration of $10 \mu \mathrm{M}$. However, at a concentration equal or above $2 \mu \mathrm{M}$, paclitaxel and docetaxel caused a similar level of apoptosis in all three cell lines. More interestingly, the percentage of apoptotic cells actually decreased at drug concentrations higher than $2 \mu \mathrm{M}$ in all three cell lines. These results indicate that the resistance of MCF-7 TXT $_{\text {TX }}$ cells to paclitaxel/docetaxel is due to their resistance to apoptosis induced by paclitaxel/docetaxel.

It is clear that paclitaxel/docetaxel induce cell apoptosis by stabilizing the microtubule spindle, arresting the cell at $M$ phase. We next examined whether the resistance to paclitaxel/docetaxel-induced apoptosis in MCF- $7_{\text {TXT }}$ cells is due to resistance to drug-induced tubulin polymerization. As shown in Figure $4 A \& B$, in the absence of paclitaxel/docetaxel, cells go through the cell cycle with the formation of normal tubulin spindle in $\mathrm{M}$ phase (Figure $4 \mathrm{~A} \& \mathrm{~B}$, Control). However, at $10 \mathrm{nM}$, paclitaxel/docetaxel begins to arrest MCF-7 and MCF-7 ${ }_{\text {DOX }}$ cells in M phase by interfering with the assembling/disassembling microtubule spindle, which leads to 
Figure 2 The expression and localization of $A B C$ proteins.

(A) The expression of various $A B C$ proteins including $A B C B 1, A B C C 1$

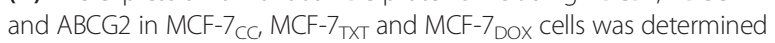
by immunoblotting with specific antibodies. (B) Quantification of the data from three independent experiments as described in panel $\mathbf{A}$. The intensity of the bands of $A B C$ proteins was normalized against the intensity of the actin loading. The error bar is standard error. ** indicates that the difference is statistically significant with $p<0.01$. (C) Immunofluorescence. The expression and the localization of various $A B C$ proteins including $A B C B 1, A B C C 1$ and $A B C G 2$ in $M C F-7 C C$,

MCF-7 TXT $_{\text {T }}$ and MCF-7 DOX $_{\text {Cells }}$ was determined by indirect immunofluorescence. The green indicates the $A B C$ proteins and the blue is the DAPI stain for nucleus. Size bar: $10 \mu \mathrm{m}$.

cell apoptosis as revealed by nuclear condensation. However, in MCF-7 $7_{\text {TXT }}$ cells, $10 \mathrm{nM}$ of paclitaxel/docetaxel did not interfere with microtubule spindle assembling/ disassembling, which was revealed by the presence of mitotic cells with normal microtubule spindles. For MCF-7 ${ }_{\mathrm{CC}}$ and MCF-7 ${ }_{\mathrm{DOx}}$ cells, the increase in concentration of paclitaxel/docetaxel from $10 \mathrm{nM}$ to $500 \mathrm{nM}$ caused an increased prevalence of $M$ phase arrest by forming abnormal mitotic spindles. On the other hand, it also stimulated strong microtubule formation for cells in interphase as revealed by the thick microtubule fibers throughout the cell. For the same range of paclitaxel/ docetaxel concentration, we observed few abnormal mitotic spindles and did not observe any significant change in the microtubule formation in MCF-7 $7_{\text {TXT }}$ cells. With a further increase of the concentration from $500 \mathrm{nM}$ to $10 \mu \mathrm{M}$, more MCF-7 $7_{\mathrm{TXT}}$ cells were arrested at $\mathrm{M}$ phase with abnormal mitotic spindles and the formation of microtubule fibres was strongly enhanced in interphase cells. For MCF-7 $\mathrm{CC}$ and MCF-7 ${ }_{\mathrm{DOX}}$ cells, the percentages of the cells arrested at $M$ phase with abnormal mitotic spindles were not changed significantly with the increase of the drug concentration from $500 \mathrm{nM}$ to $10 \mu \mathrm{M}$, but microtubule formation in interphase cells was further enhanced. At a concentration of $50 \mu \mathrm{M}$, fewer cells were arrested at $M$ phase with abnormal mitotic spindles, but microtubule fibres were thicker and formed circles at the cell periphery in both $\mathrm{MCF}-7_{\mathrm{CC}}$ and $\mathrm{MCF}-7_{\mathrm{DOx}}$ cells. Similar effects were observed in MCF- $7_{\text {TXT }}$ cells, but to a lesser degree (Figure 4A\&B).

Together, these results indicate that at a concentration as high as $500 \mathrm{nM}$, paclitaxel/docetaxel do not cause significant formation of abnormal mitotic spindles and abnormal microtubule fibres in the taxane-resistant MCF- $7_{\text {TXT }}$ cells. The resistance of MCF- $7_{\text {TXT }}$ cell to paclitaxel/docetaxel is likely due to the insensitivity of its microtubule system to the drugs.

We also examine the effects of doxorubicin on the apoptosis and microtubule formation. As shown in Figure 5, very few cells were arrested at the $M$ phase with an increased concentration of doxorubicin. Very few cells 


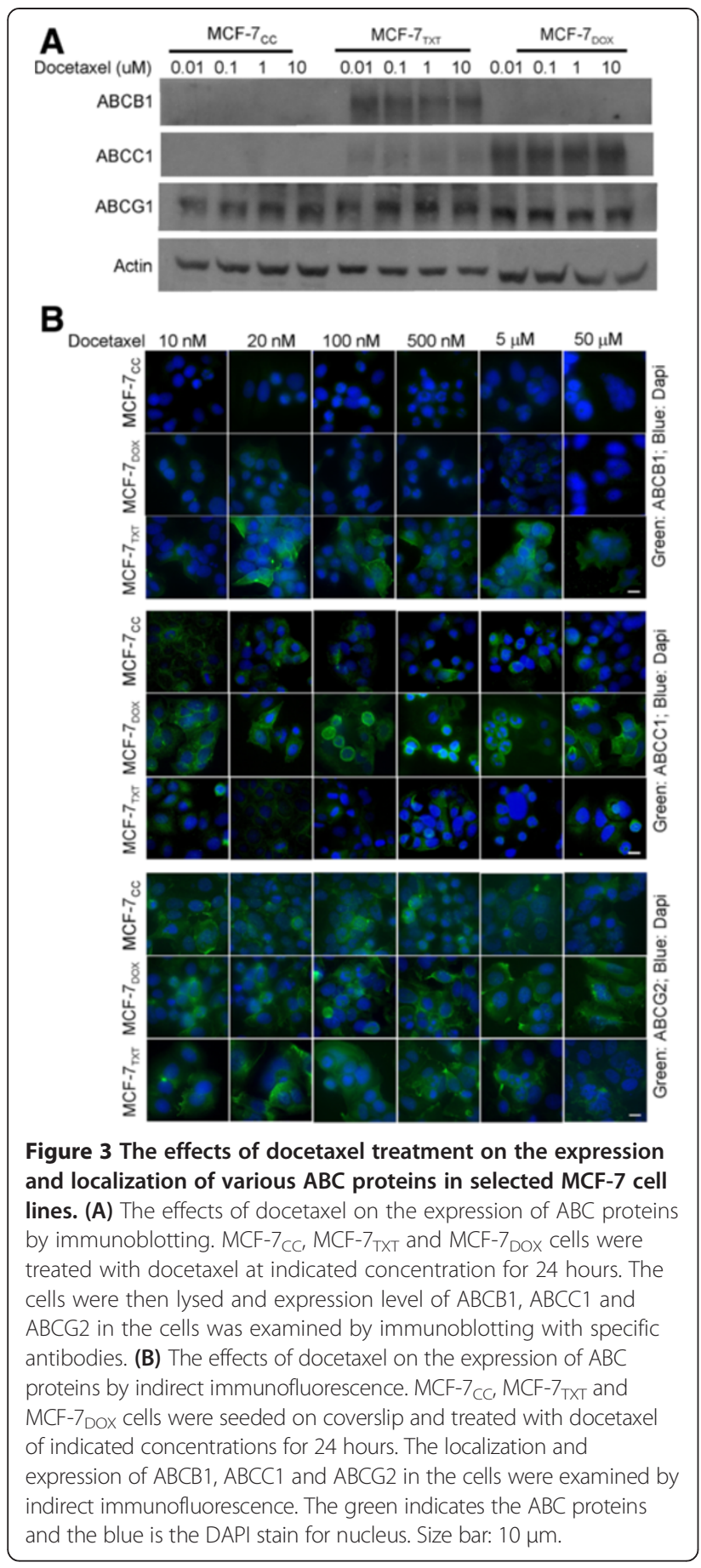

showed condensed chromatin and fragmented nuclei even at high doxorubicin concentrations. Very few cells were left on the coverslips when the doxorubicin concentration was above $1 \mu \mathrm{M}$ in $\mathrm{MCF}-7_{\mathrm{CC}}$ and MCF- $7_{\mathrm{TXT}}$ cells, or when the concentration was above $5 \mu \mathrm{M}$ in MCF-7 ${ }_{\mathrm{DOX}}$ cells. We have shown in Figure 1 that at $1 \mu \mathrm{M}$, more than $50 \%$ of the MCF-7 $7_{\mathrm{CC}}$ and MCF- $7_{\mathrm{TXT}}$ cell were killed by doxorubicin, and at $5 \mu \mathrm{M}$, more than $50 \%$ of the
MCF-7 $7_{\text {DOX }}$ cells were killed by doxorubicin. Thus, it seemed that the dead cells detached from the coverslip following their treatment with doxorubicin.

\section{Live imaging of chromatin condensation induced by docetaxel}

We next employed a live imaging approach to examine the effects of docetaxel on chromatin condensation (an indicator for cell apoptosis). As shown in Figure 6A and Additional file 1: Video S1, at a concentration of $20 \mathrm{nM}$, docetaxel had no noticeable effects on the progression of mitosis in MCF- $7_{\text {TXT }}$ cells. The cell cycle smoothly passed through $\mathrm{M}$ phase with normal chromosome pairing and segregation. However, for MCF- $7_{\mathrm{CC}}$ cells, the same concentration of docetaxel disrupted the normal movement of chromosomes at $\mathrm{M}$ phase and resulted in $\mathrm{M}$-phase arrest, leading to chromatin condensation (Figure 6B, Additional file 1: Video S2A\&B). For MCF-7 ${ }_{\text {TXT }}$ cells, a concentration of $500 \mathrm{nM}$ is needed for docetaxel to disrupt chromosome movement during $\mathrm{M}$ phase and arrest the cells at $\mathrm{M}$ phase with condensed chromatin (Figure 6C and Additional file 1: Video S3A\&B).

\section{The effects of docetaxel on microtubule dynamics of MCF-7 $7_{\text {TXT }}$ cells}

To further determine whether the resistance of MCF- $7_{\mathrm{TXT}}$ cells to docetaxel is related to the insensitivity of its microtubule polymerisation/depolymerisation to the drugs, we examined the effects of docetaxel on microtubule dynamics by live imaging (time-lapse microscopy). We transiently expressed GFP-tubulin in MCF- $7_{\mathrm{TXT}}$ and MCF- $7_{\mathrm{CC}}$ cells for $24 \mathrm{~h}$. At the flat lamellar edge of interphase cells, GFP-labeled microtubules are readily visible and can be followed by time-lapse fluorescence microscopy. Microtubule dynamics were measured by the extending and shortening of the microtubules and expressed as $\mu \mathrm{m} / \mathrm{sec}$. As shown in Figure 7, in the absence of docetaxel treatment, the microtubules were more dynamic in $\mathrm{MCF}-7_{\mathrm{CC}}$ cells than in MCF- $7_{\text {TXT }}$ cells. Both the extending rate and the shortening rate of microtubules in MCF- $7_{\mathrm{TXT}}$ cells were significantly lower than those in $\mathrm{MCF}-7_{\mathrm{CC}}$ cells (Figure 7A\&B, Additional file 2: Figure S1, Additional file 3: Video S4\&5). However, the microtubule dynamics in MCF- $7_{\text {TXT }}$ cells were much less sensitive to docetaxel than those in MCF- $7_{\mathrm{CC}}$ cells. At $100 \mathrm{nM}$ of docetaxel, both the extending rate and the shortening rate of microtubules were slightly decreased in MCF-7 ${ }_{\mathrm{CC}}$ cells, but not in MCF-7 ${ }_{\text {TXT }}$ cells (Figure 7A\&B, Additional file 4: Figure S2, Additional file 3: Video S6\&7). At a concentration of $0.5 \mu \mathrm{M}$, while both the extending rate and the shortening rate of microtubules were greatly decreased in $\mathrm{MCF}-7_{\mathrm{CC}}$ cells, microtubule dynamics were only slightly inhibited in MCF-7 $7_{\text {TXT }}$ cells (Figure $7 \mathrm{~A}, \mathrm{~B} \& \mathrm{C}$, Additional file 3: Video S8\&9). At $10 \mu \mathrm{M}$ docetaxel, the microtubules in 


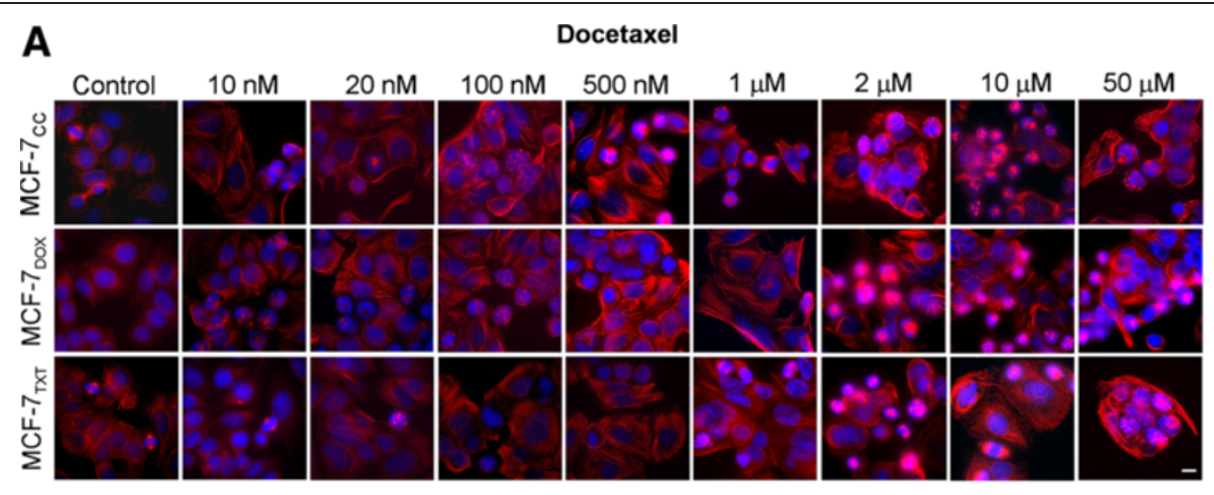

B
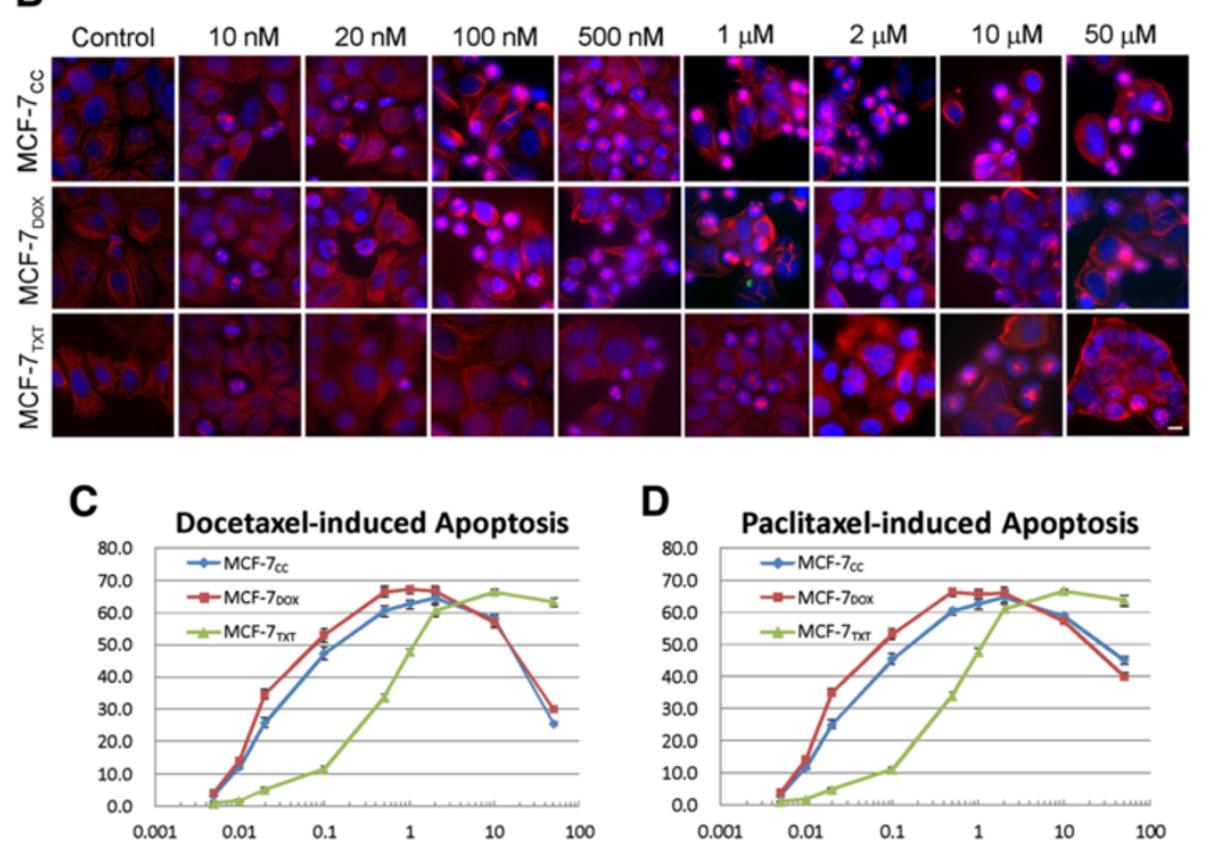

D

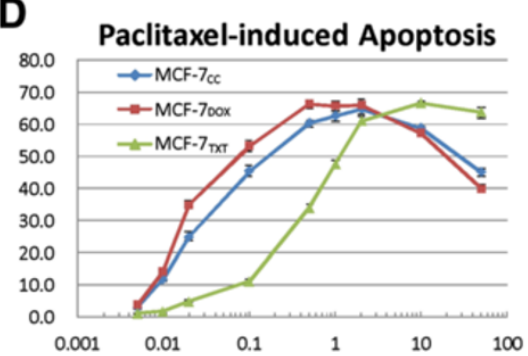

Figure 4 The effects of taxanes on the microtubule formation, M-phase arrest and cell apoptosis on the selected MCF-7 cell lines.

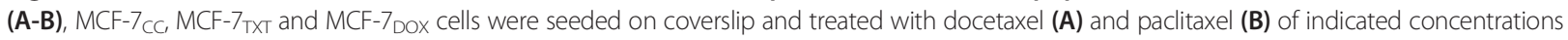
for 24 hours. The microtubule formation, M-phase arrest and cell apoptosis were determined by fluorescence microscopy. The red indicates the a-tubulin and the blue is the DAPI stain for DNA. Size bar: $10 \mu \mathrm{m}$. (C\&D) The effects of docetaxel (C) and paclitaxel (D) on the apoptosis of MCF-7 CC, MCF-7 TXT $_{\text {and MCF-7 }}$ Dox Cells. The apoptotic cells were determined by chromatin condensation and nuclear morphology as revealed by DAPI stain in A \& B. For each data, 300 cells from at least three independent experiments were examined. The error bar is the standard error.

both $\mathrm{MCF}-7_{\mathrm{CC}}$ and $\mathrm{MCF}-7_{\mathrm{TXT}}$ cells were almost completely stabilized with very low extending and shortening rate (Figure 7A\&B, Additional file 5: Figure S3, Additional file 3: Video S10\&11). These results indicate that MCF- $7_{\text {TXT }}$ cells may have less vigorous intrinsic microtubule dynamics than $\mathrm{MCF}-7_{\mathrm{CC}}$ cells. The microtubule dynamics in MCF- $7_{\text {TXT }}$ cells were ten times less sensitive to docetaxel treatment. This insensitivity to docetaxel contributes to the resistance of MCF- $7_{\mathrm{TXT}}$ cells to docetaxel.

The expression levels of $\beta$-tubulin isoforms in MCF- $7_{\mathrm{TXT}}$, MCF-7 $7_{\text {Dox }}$, and MCF-7 $7_{C C}$ cells

We next examined the expression level of various $\beta$ tubulin isoforms because it has been reported that the microtubule dynamics may be related to the expression level of various $\beta$-tubulin isoforms $[3,4,14]$. The expression of $\alpha$-tubulin and various $\beta$-tubulin isoforms including $\beta 1$-, $\beta 2-, \beta 3-$ and $\beta 4-$ tubulin was examined in MCF-7 TXT, MCF- $7_{\mathrm{DOX}}$ and MCF- $7_{\mathrm{TXT}}$ cells by immunoblotting and immunofluorescence. As shown in Figure 8A, the expression levels of $\alpha$-tubulin and $\beta 1$-tubulin were high and very similar in the three MCF-7 cell lines. However, the expression levels of other $\beta$-tubulins were different. The expression level of $\beta 3$-tubulin in MCF-7 ${ }_{\text {TXT }}$ cells was significantly lower than that in $\mathrm{MCF}-7_{\mathrm{CC}}$ and $\mathrm{MCF}-7_{\mathrm{DOx}}$ cells $(\mathrm{p}<0.01)$. On the other hand, the expression levels of $\beta 2-$ and $\beta 4$-tubulin in MCF-7 ${ }_{\text {TXT }}$ cells were significantly higher than that in $\mathrm{MCF}-7_{\mathrm{CC}}$ and MCF-7 ${ }_{\mathrm{DOx}}$ cells $(\mathrm{p}<0.01)$. 


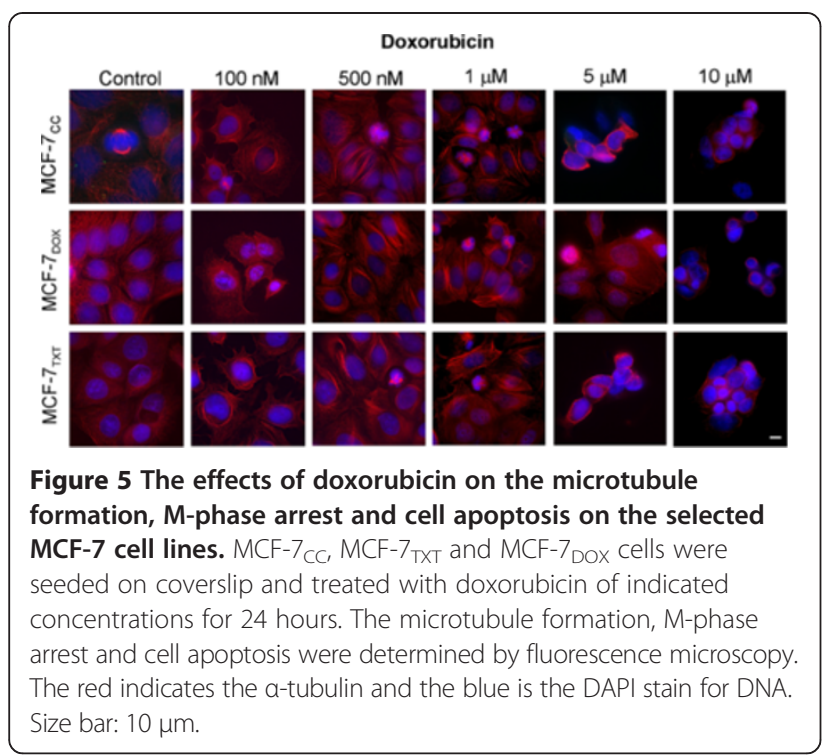

We also examined the expression and localization of the $\alpha$-tubulin and various $\beta$-tubulin isoforms in $\mathrm{MCF}^{-} 7_{\mathrm{CC}}$, MCF-7 $7_{\text {TXT }}$ and MCF-7 ${ }_{\text {DOX }}$ cells by indirect immunofluorescence (Figure 8B). As shown in Figure 8B, $\alpha$-tubulin stain showed clear and intact microtubules in all three cell lines. The $\beta 3$ - and $\beta 4$-tubulins stain also showed clear and intact microtubules in both $\mathrm{MCF}-7_{\mathrm{CC}}$ and $\mathrm{MCF}-7_{\mathrm{DOX}}$ cells, but to a lesser extent in MCF-7 ${ }_{\mathrm{TXT}}$ cells. However, staining of the $\beta 1$ - and $\beta 2$-tubulin did not appear like microtubules, but rather small dots filled the cytoplasm of the cells. The pattern of these small tubulin dots is more defined and localized discontinuously along the microtubules in both MCF-7 $7_{\mathrm{CC}}$ and MCF-7 ${ }_{\mathrm{DOx}}$ cells. However, the patterns of these small tubulin dots are messy and less defined along the microtubule fibers in MCF- $7_{\mathrm{TXT}}$ cells. Another difference between MCF- $7_{\mathrm{TXT}}$ cell and
MCF-7 ${ }_{\text {CC }} /$ MCF-7 $7_{\text {Dox }}$ cell is that in MCF-7 $7_{\text {TXT }}$ cells, the $\beta 1$ - and $\beta 2$-tubulin are localized more at the perinuclear region of the cell while the $\beta 3$ - and $\beta 4$-tubulin were localized more at the peripheral region of the cell.

Together, our results showed that the expression and localization of the various $\beta$-tubulin isoforms were significantly altered in MCF-7 ${ }_{\mathrm{TXT}}$ cells. It is likely that the difference in the expression level of various $\beta$-tubulin isoforms and their subcellular localization between MCF- $7_{\text {TXT }}$ cells and $\mathrm{MCF}-7_{\mathrm{CC}} / \mathrm{MCF}-7_{\mathrm{DOx}}$ cells contributes to the differences in their observed microtubule dynamics and resistance to taxanes.

\section{Discussion and conclusion}

To better understand the mechanisms underlying acquired resistance to taxanes in breast cancer, we utilized previously established cell lines in which MCF-7 breast cancer cells were selected for survival in increasing concentrations of doxorubicin (MCF-7Dox cells) or docetaxel (MCF-7 ${ }_{\mathrm{TXT}}$ cells) [25]. A cell line selected under identical conditions in the absence of drug $\left(\mathrm{MCF}-7_{\mathrm{CC}}\right)$ was used as a control.

We showed that MCF-7 ${ }_{\text {TXT }}$ cells that are resistant to docetaxel are cross resistant to other drugs in the same group such as paclitaxel, but are not resistant to doxorubicin, a different type of cancer drug (Figure 1). Similarly, we showed that MCF-7 $7_{\text {DOx }}$ cells are resistant to doxorubicin, but not resistant to both docetaxel and paclitaxel. These results demonstrate that the acquired chemoresistance in this instance is specific to the selection agent and it is not a consequence of the establishment of mechanisms of multidrug resistance. Our finding is different from a previous report showing that drug resistant MCF-7 cells lines also develops cross-resistance to structurally unrelated cancer drugs [27]. However, in this previous

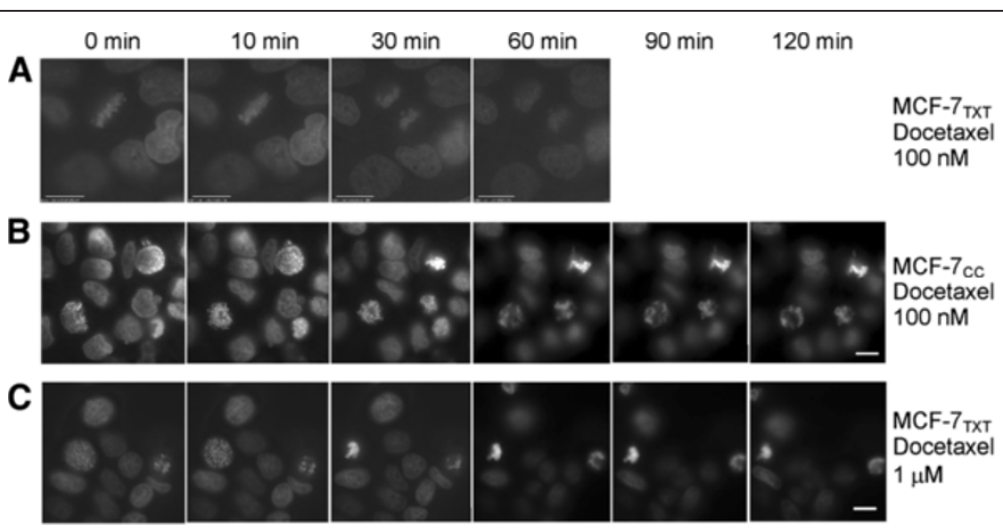

Figure 6 The effects of docetaxel on the M-phase arrest in MCF-7 $\mathbf{C c}$ and MCF-7 $\mathbf{T}_{\text {TXT }}$ cells. The effects of docetaxel on the chromosome condensation and M-phase arrest of MCF-7 CC and MCF-7 TXT cells were examined by live imaging. MCF-7 cells were incubated with DMEM containing $250 \mathrm{ng} / \mathrm{ml}$ Hoechst 33342 (Calbiochem) for 10 minutes to stain DNA. Then, the cells were incubated with docetaxel of indicated concentration. The images of cell mitosis were recorded every 2 minutes by live imaging. (A) MCF-7TXT cells treated with 100 nM Docetaxel. (B) MCF-7CC cells treated with 100 nM Docetaxel. (C) MCF-7TXT cells treated with $1 \mu$ M Docetaxel. The Size bar: $10 \mu \mathrm{m}$. 

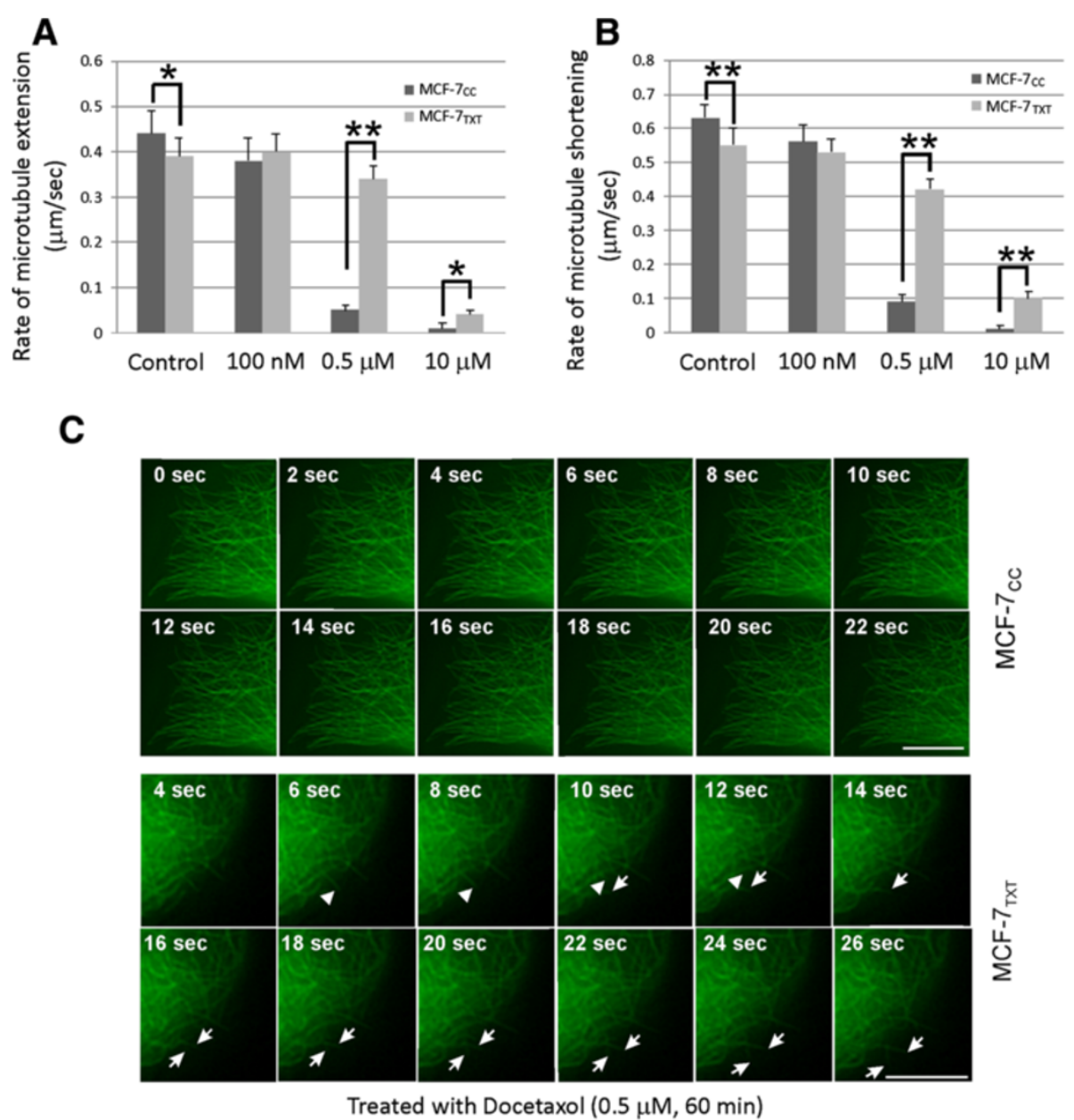

Figure 7 The effects of docetaxel on the microtubule dynamics of MCF- $7_{\mathrm{TXT}}$ an MCF- $7_{\mathrm{CC}}$ cells. The Live imaging was performed as described in Methods. Following the transfection of the cells with GFP-tagged a-tubulin for 24 hours, the cells were incubated with docetaxel of indicated concentration for 1 hour. The images of microtubule dynamics of MCF-7 $C$ and MCF-7 $7_{T X T}$ Cells were recorded every 2 seconds by live imaging. The extension rate (A) and shortening rate (B) of microtubules were measured from the recorded images. Each datum is the average of 20 measurements from at least 8 different cells. The error bar is the standard error. * indicates that the difference is statistically significant with $p<0.05$. ** indicates that the difference is statistically significant with $p<0.01$. (C) Selected images from the live imaging (Additional file 3: Video S8\&9) of microtubule dynamics of MCF-7 $\mathrm{CC}_{\text {and }}$ MCF-7 $7_{\mathrm{TXT}}$ cells following treatment with $0.5 \mu \mathrm{M}$ docetaxel for 1 hour. Arrow indicates the extending microtubules. Arrow head indicates the shortening microtubules. Size bar, $10 \mu \mathrm{m}$.

report, it is also shown that selected paclitaxel-resistant MCF-7 cell is not cross-resistant to doxorubicin, which is consistent to our data. Nevertheless, our data suggest that the acquired resistance can be specific and chemotherapy using combined drugs or alternative drugs may overcome the resistance. Indeed, sequential single-agent therapy or combination therapy have been used in breast cancer treatment to overcome drug resistance [28].

We further showed that the selected chemoresistant cell lines do have higher expression level of certain ABC transporter proteins (Figure 2). The expression level of ABCB1 is very high only in MCF-7 TXT cells and the expression level of $\mathrm{ABCC} 1$ is very high only in MCF-7 Dox cells. The expression level of ABCG2 is similar in both the selected chemoresistant and the parental MCF-7 cell lines and likely did not play a role in the drug-resistant phenotypes of these cell lines. These observations are consistent with our previous findings regarding the transcription of these ABC transporter genes in various selected MCF-7 cells [25]. We also showed previously that MCF-7 ${ }_{\text {TXT }}$ cells have lower accumulation of paclitaxel and MCF-7 $7_{\text {DOx }}$ cells have lower accumulation of doxorubicin [25]. While all of these three $\mathrm{ABC}$ proteins have been implicated in multiple drug resistance including taxanes and doxorubicin $[1,3,4,14,29]$, our results suggest that the specific member of $\mathrm{ABC}$ transporter proteins that are induced during the selection process may be different depending upon the selection agent. Our results indicate that the resistance to taxanes in MCF-7 ${ }_{\text {TXT }}$ cells is associated with high expression level of the $\mathrm{ABCB} 1$ protein, but not $\mathrm{ABCC} 1$ and 


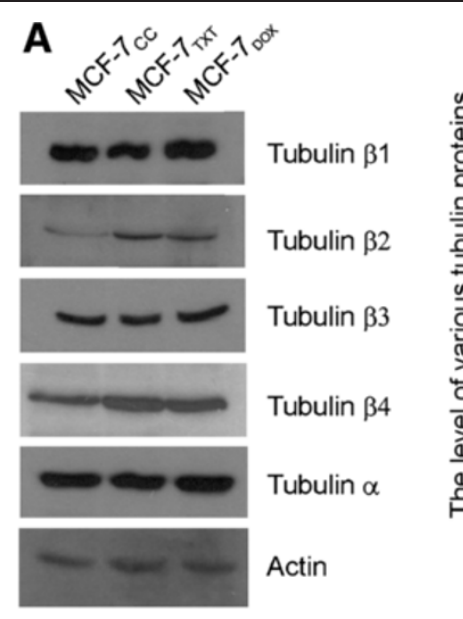

\section{B}
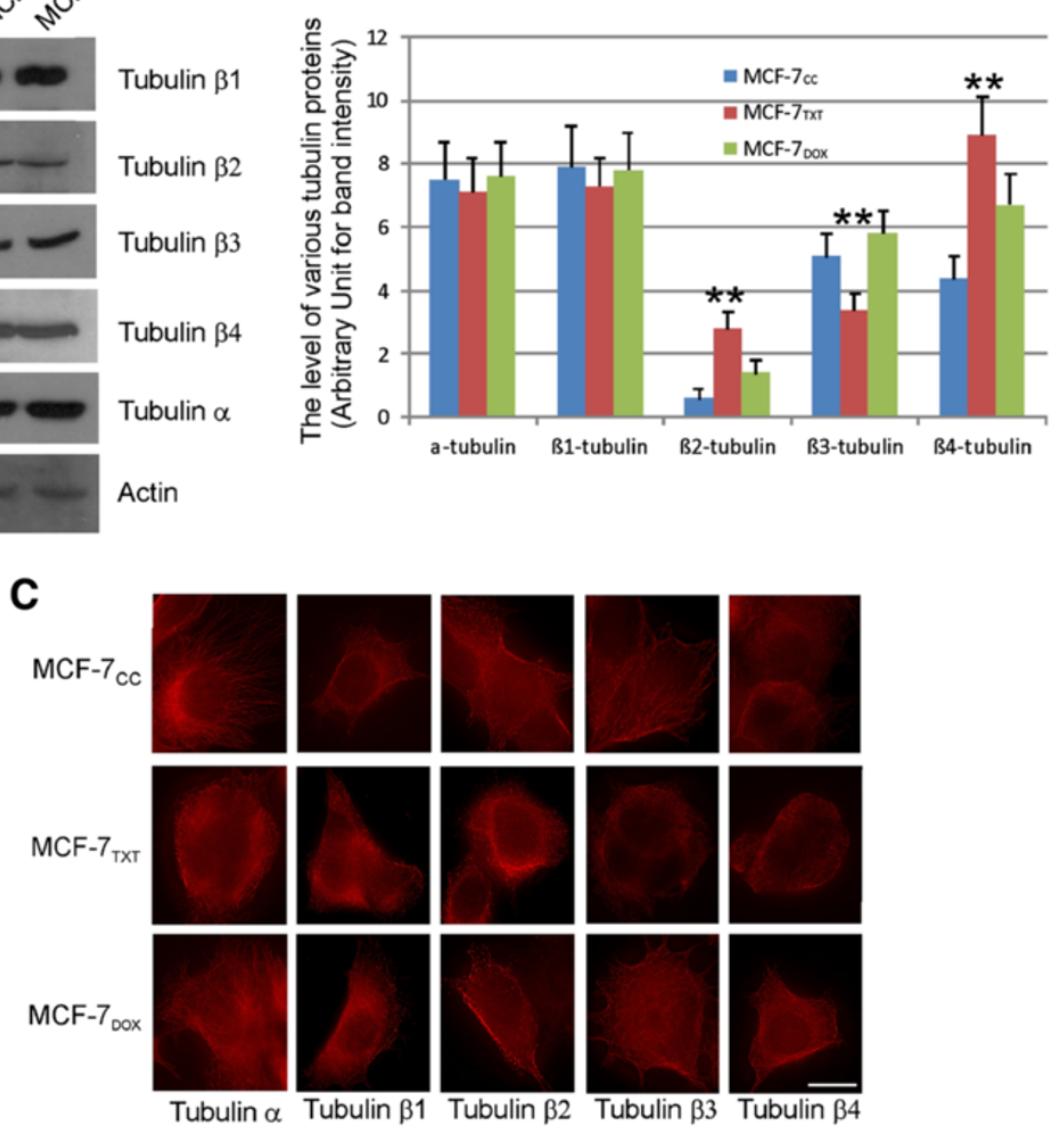

Figure 8 The expression and localization of various $\beta$-tubulin isoforms in selected MCF-7 cells. (A) The expression of a-tubulin and various

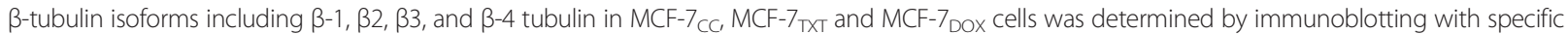
antibodies. (B) Quantification of the data from three independent experiments as described in panel $\mathbf{A}$. The intensity of the bands of various tubulin proteins was normalized against the intensity of the actin loading. The error bar is standard error. ${ }^{* *}$ indicates that the difference is statistically significant with $p<0.01$. (C) Immunofluorescence. The expression and the localization of various tubulin proteins including $\alpha-, \beta 1-, \beta 2-, \beta 3-$, and

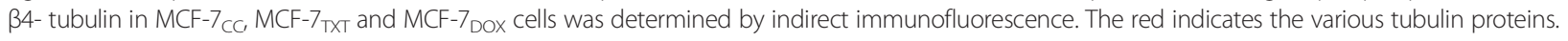
Size bar: $10 \mu \mathrm{m}$.

ABCG2, which is consistent with previous findings in other cell lines [19]. Although ABCB1, ABCC1 and ABCG2 are all implicated in the resistance to doxorubicin [19], the lack of cross-resistance to doxorubicin in MCF$7_{\text {TXT }}$ cells suggests that the ABCB1 overexpression alone may not efficiently mediate the efflux of doxorubicin in this selected MCF-7 cell line. Moreover, the overexpression of ABCC1, but not ABCB1 in MCF-7 gests that the resistance to doxorubicin is associated with high expression of the ABCC1 protein and lack of overexpression of ABCB1 does not block the ability of cells to acquire the resistance to doxorubicin. The lack of crossresistance to taxanes in $\mathrm{MCF}-7_{\mathrm{DOX}}$ cells also support the previous finding that $\mathrm{ABCC} 1$ may be more efficient in mediating the efflux of doxorubicin, but not taxane $[19,28]$. Given that the expression of ABCG2 protein was similar amongst MCF-7CC, MCF-7TXT, and MCF-7DOX cells, our data also suggest that resistance to either taxanes or doxorubicin is unrelated to ABCG2 expression. Our observation that treatment of the above cell lines with docetaxel for $24 \mathrm{~h}$ did not alter the expression and localization of these $\mathrm{ABC}$ proteins (Figure 3) also suggests that docetaxel itself cannot induce the expression of $\mathrm{ABC}$ transporter proteins.

It is also likely that the overexpression of any one of the above $A B C$ proteins is not sufficient to confer the resistance to chemotherapy and other mechanisms are responsible for the resistance. Indeed, as we showed previously, while the drug resistance is related to the expression of drug transporters and the drug accumulations in the cells, drug transporter inhibitors are insufficient to fully restore sensitivity of MCF-7 DOx cells to doxorubicin or MCF- $7_{\text {TXT }}$ cells to docetaxel [25]. A series of experiments are performed in this study to provide insight into the 
additional mechanisms underlying resistance to taxanes in these cells.

We show in this study that the acquired resistance of MCF-7 ${ }_{\text {TXT }}$ cells to taxanes as revealed in cytotoxicity assay (Figure 1) is also associated with resistance to taxaneinduced apoptosis as revealed by quantification of chromosome condensation (Figure 4). While some studies suggest that MCF-7 cells are unable to go apoptosis due to the deletion of caspase-3 gene and thus the lack of caspase- 3 protein, other studies indicate that MCF-7 cells are able to go apoptosis due to the existence of caspase- 3 independent apoptotic pathways [30-36]. We found in the cytotoxicity assay that the total of surviving cells follow a two-phase decrease with the increase of the concentration of docetaxel and paclitaxel (Figure 1). A sharp decrease at the low dose range $(<1 \mu \mathrm{M})$ and a further decrease at the high dose rage $(>10 \mu \mathrm{M})$ following a plateau at the middle dose range $(1-10 \mu \mathrm{M})$. This observation is consistent with our previous report [37]. We further showed in this study that taxane treatment arrested the cells at $M$ phase at the dosage lower than $1 \mu \mathrm{M}$, which eventually leads to cell apoptosis (Figure 4A). The first phase of decrease in cell population (Figure 1) is coincident with the increase of cell apoptosis induced by the treatment of docetaxel and paclitaxel (Figure 4), which suggest that taxane-induced apoptosis is likely responsible for the reduction of cell population at the doses less than $1 \mu \mathrm{M}$. On the other hand, treatment of the cells with doxorubicin did not arrest the cells at $M$ phase and did not induce significant cell apoptosis (Figure 5). It has been reported that doxorubicin interacts with topoisomerases I and II [10] leading to DNA damage followed by G1 and G2 growth arrest, which has been proposed to correlate with tumor response and patient's outcome [1,11]. The few apoptotic cells induced by doxorubicin observed under a fluorescence microscope could be due to the detaching of the apoptotic cells from the coverslip.

The interaction between taxanes and the microtubules stabilises microtubules by reducing depolymerisation. Stabilization of microtubules by taxane binding prevents normal formation of mitotic spindles [6]. This leads to chronic activation of the spindle assembly checkpoint (SAC), which in turn leads to mitotic arrest [7]. Extended mitotic arrest eventually leads to cell death [8]. We studied the effects of taxanes on the formation of microtubules and the mitotic spindles in MCF- $7_{\mathrm{TXT}}$, MCF-7 $7_{\text {DOX }}$ and $M C F-7_{\mathrm{CC}}$ cells by indirect immunofluorescence (Figure 4A). We showed that the abnormal mitotic spindles induced by taxane treatment are accompanied by the arrest of cells at $\mathrm{M}$ phase and the initiation of cell apoptosis (nuclear condensation). While 10 - $100 \mathrm{nM}$ of docetaxel and paclitaxel induced significant mitotic spindle disruption and $\mathrm{M}$ phase arrest in $\mathrm{MCF}-7_{\mathrm{CC}}$ and MCF-7 ${ }_{\text {DOX }}$ cells, ten times higher concentrations of docetaxel and paclitaxel are needed to induce a similar level of mitotic spindle disruption and $M$ phase arrest in MCF- $7_{\text {TXT }}$ cells. Thus, our data clearly suggests that the acquired resistance to taxanes in MCF- $7_{\text {TXT }}$ cells is due to the resistance to taxane-induced mitotic spindle disruption and $M$ phase arrest.

We also examined microtubule dynamics in MCF-7 ${ }_{\text {TXT }}$ cells (Figure 7, Additional file 2: Figure S1, Additional file 4: Figure S2, Additional file 5: Figure S3 and Additional file 3: Video S4-10). We showed that in the absence of docetaxel treatment the microtubule dynamics are robust in both MCF- $7_{\text {TXT }}$ and $\mathrm{MCF}-7_{\mathrm{CC}}$ cells, but the microtubule dynamics are weaker in MCF-7 ${ }_{\text {TXT }}$ cells than that in MCF- $7_{\mathrm{CC}}$ cells. Moreover, microtubule dynamics are greatly more insensitive to docetaxel in MCF-7 ${ }_{\text {TXT }}$ calls than in $\mathrm{MCF}-7_{\mathrm{CC}}$ cells. For example, treatment with $0.5 \mu \mathrm{M}$ docetaxel only slightly reduces the microtubule dynamics in MCF- $7_{\text {TXT }}$ cells, but significantly reduced both the shortening and extending rate of microtubules in MCF- $7_{\mathrm{CC}}$ cells. Our findings suggest that the resistant MCF-7 ${ }_{\text {TXT }}$ cells have unique microtubule dynamics that are likely unrelated to the overexpression of $\mathrm{ABC}$ transporters. The insensitivity of microtubules to docetaxel treatment in MCF-7 ${ }_{\mathrm{TXT}}$ cells may be partially the reason that docetaxel is less effective in inducing the M-phase arrest and the apoptosis in MCF-7 ${ }_{\text {TXT }}$ cells in comparison to $\mathrm{MCF}-7_{\mathrm{CC}}$ cells. This unique microtubule dynamics may contribute to the resistance to docetaxel.

Although taxane-binding sites on microtubules are only present in assembled tubulin [38], the stabilized microtubules are not able to extend without depolymerisation. It is interesting to note that $0.5 \mu \mathrm{M}$ docetaxel induces very high level $\mathrm{M}$-phase arrest at MCF- $7_{\text {TXT }}$ cells (Figures 1 and 4), but does not significantly reduce the microtubule dynamics in MCF-7 ${ }_{\text {TXT }}$ cells (Figure 7). Similarly, $100 \mathrm{nM}$ of docetaxel induces very high level M-phase arrest at MCF-7 $\mathrm{CC}$ cells (Figures 1 and 4), but does not significantly reduce the microtubule dynamics in MCF-7 ${ }_{\mathrm{CC}}$ cells (Figure 7). The reason for this could be the duration of the treatment. We assayed the M-phase arrest and cell apoptosis following the treatment for $24 \mathrm{~h}$, but we assayed the microtubule dynamics only after the treatment for $1 \mathrm{~h}$. Besides, multiple mechanisms are involved in the acquired resistance to docetaxel, microtubule dynamics is just one of these mechanisms.

Finally, we showed that the all four $\beta$-tubulin isoforms are expressed in the three MCF-7 cell lines. While the relative expression levels of the four $\beta$-tubulin isoforms are very similar between $\mathrm{MCF}-7_{\mathrm{DOX}}$ and $\mathrm{MCF}-7_{\mathrm{CC}}$ cells, the relative expression levels of the $\beta$-tubulin isoforms are quite different in MCF-7 $7_{\text {TXT }}$ cells (Figure 8). MCF- $7_{\text {TXT }}$ cells have relatively higher $\beta 2$ - and $\beta 4$-tubulin expression and relatively lower $\beta 3$-tubulin expression level (Figure 8). These results suggest that the expression level of various 
$\beta$-tubulin isoforms is related to the microtubule dynamics of the MCF-7 cells in response to docetaxel treatment. The expression levels of various tubulin isoforms have been linked to the resistance to taxanes in breast cancers. It has been reported that both $\beta 3$ - and $\beta 4$-tubulin are overexpressed in a MCF-7 cell line selected for resistant to paclitaxel under increased paclitaxel concentration [21]. The overexpression of $\beta 3$-tubulin induces paclitaxel resistance by reducing the ability of paclitaxel to suppress microtubule dynamics [20]. It is also reported that mRNA levels of $\beta 2-, \beta 3$ - and $\beta 4$-tubulin are significantly upregulated in paclitaxel- and docetaxel-resistant MCF-7 cells [23]. The MCF-7 ${ }_{\text {TXT }}$ cell line used in this research is selected for resistance to docetaxel, but showed similar resistance to paclitaxel. While we also found that MCF-7 TXT cells have higher $\beta 2$ - and $\beta 4$-tubulin expression than

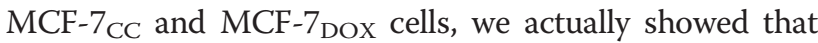
the $\beta 3$-tubulin expression level is lower. The significant difference in the expression levels of various $\beta$-tubulin isoforms suggest that the composition of $\beta$-tubulin in the formation of microtubules may contribute to the microtubule dynamics and its response to taxane treatment, which could be part of the mechanisms underlying the acquired resistance to taxanes in breast cancer cells.

We also examined the localization of these tubulin isoforms. We showed that the localization pattern of the various $\beta$-tubulin isoforms in MCF-7 ${ }_{\mathrm{TXT}}$ cells is different from that of MCF-7 $\mathrm{CC}$ and MCF-7 $7_{\mathrm{DOX}}$ cells (Figure $8 \mathrm{~B}$ ). While we did not know how the different subcellular distribution of these $\beta$-tubulin isoforms affects its response to docetaxel treatment, it is possible that the relative composition of various $\beta$-tubulin isoforms in microtubules and their formation pattern may play a role in determining microtubule dynamics and sensitivity of microtubules to docetaxel treatment.

As shown from this study, multiple mechanisms are likely involved in the acquired drug resistance. Besides discussed above, many other proteins and mechanisms may also be involved in the acquired drug resistance. It has been shown that extracellular matrix proteins, apoptosis related proteins, cytokine and growth factor signaling proteins, and many other proteins are overexpressed in the selected MCF-7 cells resistant to taxanes and other cancer drugs $[29,39,40]$. It is interesting to find out in the future study whether and how these different mechanisms regulate drug-resistance independently or coordinately.

In conclusion, our results suggest the presence of multiple mechanisms for acquired drug resistance to taxanes. Prolonged exposure to taxanes may result in the selection of the breast cancer cells that overexpress certain drug resistance proteins, such as ABCB1 in MCF- $7_{\text {TXT }}$ cells, which will lower the taxane level inside the cells and thus contribute to the resistance to taxanes. Prolonged exposure to taxanes may also result in the selection of the breast cancer cells that have differential expression of various $\beta$-tubulin isoforms, such as higher $\beta-2$ and $\beta-4$ and lower $\beta-3$ tubulin in MCF-7 TXT cells. In addition, the relative composition of various $\beta$-tubulin isoforms within the microtubules and the specific distribution of these $\beta$-tubulin isoforms along the microtubules may determine the dynamics of the microtubules and its sensitivity to taxane treatment. For example, in MCF- $7_{\text {TXT }}$ cells, the distinct distribution of the $\beta$-tubulin isoforms can be related to the weak microtubule dynamics and its insensitivity to taxane treatment.

\section{Additional files}

\begin{abstract}
Additional file 1: Video S1-S3. Live imaging of docetaxel-induced M-phase arrest in MCF-7wt and MCF-7txt cells. MCF-7 cells were incubated with DMEM containing 250 ng/ml Hoechst 33342 (Calbiochem) for 10 minutes to stain DNA. Then, the cells were incubated with docetaxel of indicated concentration. The images of cell mitosis were recorded every 2 minutes by live imaging. Video S1. MCF-7txt treated with $100 \mathrm{nM}$ docetaxel. Video S2A\&B. MCF-7wt cells treated with $100 \mathrm{nM}$ docetaxel. Video S3A\&B, MCF-7wt cells treated with $1 \mu \mathrm{M}$ docetaxel.
\end{abstract}

Additional file 2: Figure S1. Selected images from the live imaging (Additional file 3: Video S4\&5) of microtubule dynamics of MCF-7wt (A) and MCF-7txt (B) cells without docetaxel treatment. Arrow indicates the extending microtubules. Arrow head indicates the shortening microtubules. Size bar, $10 \mu \mathrm{m}$.

Additional file 3: Video S4-S11. Live imaging of the micrtotubule dynamics of MCF-7wt and MCF-7txt cells following the treatment with docetaxel. The Live imaging was performed as described in Methods. Following the transfection of the cells with GFP-tagged a-tubulin for 24 hours, the cells were incubated with docetaxel of indicated concentration for 1 hour. The images of microtubule dynamics of MCF-7wt and MCF-7txt cells were recorded every 2 seconds by live imaging. Video S4. MCF-7wt cells without docetaxel treatment (Control). Video S5. MCF-7txt cells without docetaxel treatment (Control). Video S6. MCF-7wt cells treated with 100 nM docetaxel for 1 hour. Video S7. MCF-7txt cells treated with 100 nM docetaxel for 1 hour. Video S8. MCF-7wt cells treated with $0.5 \mu \mathrm{M}$ docetaxel for 1 hour. Video S9. MCF-7txt cells treated with $0.5 \mu \mathrm{M}$ docetaxel for 1 hour. Video S10. MCF-7wt cells treated with $10 \mu \mathrm{M}$ docetaxel for 1 hour. Video S11. MCF-7txt cells treated with $10 \mu \mathrm{M}$ docetaxel for 1 hour.

Additional file 4: Figure S2. Selected images from the live imaging (Additional file 3: Video S6\&7) of microtubule dynamics of MCF-7wt (A) and MCF-7txt (B) cells following treatment with $100 \mathrm{M}$ docetaxel for 1 hour. Arrow indicates the extending microtubules. Arrow head indicates the shortening microtubules. Size bar, $10 \mu \mathrm{m}$.

Additional file 5: Figure S3. Selected images from the live imaging (Additional file 3: Video S6\&7) of microtubule dynamics of MCF-7wt (A) and MCF-7txt (B) cells following treatment with $10 \mu \mathrm{M}$ docetaxel for 1 hour. Arrow indicates the extending microtubules. Arrow head indicates the shortening microtubules. Size bar, $10 \mu \mathrm{m}$.

\section{Competing interests}

All authors declare that they have no competing interests.

\section{Authors' contributions}

HW: Participating in the design of the project, performing most of the experiments including cell culture, cytotoxicity assay, immunoblotting, immunofluorescence, and living image, and participating in the data analysis and manuscript writing. TV: Performing experiments including cell culture and immunoblotting, and participating in data analysis. AH: Performing experiments including cell culture, cytotoxicity assay, and immunoblotting, and participating in data analysis. SL: Performing experiments including cell 
culture, cytotoxicity assay, and immunoblotting, and participating in data analysis. XC: Performing experiments including cell culture, cytotoxicity assay, immunoblotting, immunofluorescence, and living image, and participating in data analysis. AMP: Providing drug-resistance cell lines, participating in the design of the project, and participating in the writing of the manuscript. DNB: Participating in the design of the project, data analysis and the writing of the manuscript. ZW: Participating in the design of the project, performing some experiments including living image and immunofluorescence, and participating in data analysis and the writing of the manuscript. All authors read and approved the final manuscript.

\section{Acknowledgements}

This research is supported in part by funding from Canadian Breast Cancer Foundation (CBCF) (DNB and ZW), Alberta Innovates - Health Solution (AIHS) (DNB and ZW), and Sanofi-aventis BioTalent Challenge (SABC) (HW, AH and SL).

\section{Author details}

'Department of Medical Genetics, University of Alberta, Edmonton, AB T6G 2H7, Canada. ${ }^{2}$ Department of Biochemistry and Signal Transduction Research Group, Faculty of Medicine and Dentistry, University of Alberta, Edmonton, AB T6G 2H7, Canada. ${ }^{3}$ Regional Cancer Program, Sudbury Regional Hospital, Sudbury, ON, Canada.

Received: 10 December 2013 Accepted: 17 January 2014

Published: 22 January 2014

\section{References}

1. Lal S, Mahajan A, Chen WN, Chowbay B: Pharmacogenetics of target genes across doxorubicin disposition pathway: a review. Curr Drug Metab 2010, 11:115-128.

2. Jemal A, Bray F, Center MM, Ferlay J, Ward E, Forman D: Global cancer statistics. CA Cancer J Clin 2011, 61:69-90.

3. Murray S, Briasoulis E, Linardou H, Bafaloukos D, Papadimitriou C: Taxane resistance in breast cancer: mechanisms, predictive biomarkers and circumvention strategies. Cancer Treat Rev 2012, 38:890-903.

4. Zelnak A: Overcoming taxane and anthracycline resistance. Breast J 2010, 16:309-312.

5. Rivera E: Implications of anthracycline-resistant and taxane-resistant metastatic breast cancer and new therapeutic options. Breast J 2010, 16:252-263.

6. Jordan MA, Wilson L: Microtubules as a target for anticancer drugs. Nat Rev Cancer 2004, 4:253-265.

7. Gascoigne KE, Taylor SS: How do anti-mitotic drugs kill cancer cells? J Cell Sci 2009, 122:2579-2585.

8. Kavallaris M: Microtubules and resistance to tubulin-binding agents. Nat Rev Cancer 2010, 10:194-204.

9. Sprowl JA, Reed K, Armstrong SR, Lanner C, Guo B, Kalatskaya I, Stein L, Hembruff SL, Tam A, Parissenti AM: Alterations in tumor necrosis factor signaling pathways are associated with cytotoxicity and resistance to taxanes: a study in isogenic resistant tumor cells. Breast Cancer Res 2012, 14:R2.

10. Tewey KM, Rowe TC, Yang L, Halligan BD, Liu LF: Adriamycin-induced DNA damage mediated by mammalian DNA topoisomerase II. Science 1984 226:466-468.

11. Buchholz TA, Stivers DN, Stec J, Ayers M, Clark E, Bolt A, Sahin AA, Symmans WF, Hess KR, Kuerer HM, Valero V, Hortobagyi GN, Pusztai L: Global gene expression changes during neoadjuvant chemotherapy for human breast cancer. Cancer J 2002, 8:461-468.

12. Minotti G, Menna P, Salvatorelli E, Cairo G, Gianni L: Anthracyclines: molecular advances and pharmacologic developments in antitumor activity and cardiotoxicity. Pharmacol Rev 2004, 56:185-229.

13. Fojo T, Menefee M: Mechanisms of multidrug resistance: the potential role of microtubule-stabilizing agents. Ann Oncol 2007, 18(Suppl 5):v3-v8.

14. McGrogan BT, Gilmartin B, Carney DN, McCann A: Taxanes, microtubules and chemoresistant breast cancer. Biochim Biophys Acta 2008, 1785:96-132.

15. Szakacs G, Paterson JK, Ludwig JA, Booth-Genthe C, Gottesman MM: Targeting multidrug resistance in cancer. Nat Rev Drug Discov 2006, 5:219-234.
16. Alvarez M, Paull K, Monks A, Hose C, Lee JS, Weinstein J, Grever M, Bates S, Fojo T: Generation of a drug resistance profile by quantitation of $\mathrm{mdr}-1 /$ P-glycoprotein in the cell lines of the National Cancer Institute Anticancer Drug Screen. J Clin Invest 1995, 95:2205-2214.

17. Tsukamoto F, Shiba E, Taguchi T, Sugimoto T, Watanabe T, Kim SJ, Tanji Y, Kimoto Y, Izukura M, Takai SI: Immunohistochemical detection of Pglycoprotein in breast cancer and its significance as a prognostic factor. Breast Cancer 1997, 4:259-263.

18. Kanzaki A, Toi M, Nakayama K, Bando H, Mutoh M, Uchida T, Fukumoto M, Takebayashi Y: Expression of multidrug resistance-related transporters in human breast carcinoma. Jpn J Cancer Res 2001, 92:452-458.

19. Tamaki A, lerano C, Szakacs G, Robey RW, Bates SE: The controversial role of $A B C$ transporters in clinical oncology. Essays Biochem 2011 50:209-232.

20. Kamath K, Wilson L, Cabral F, Jordan MA: Betalll-tubulin induces paclitaxe resistance in association with reduced effects on microtubule dynamic instability. J Biol Chem 2005, 280:12902-12907.

21. Banerjee A: Increased levels of tyrosinated alpha-, beta(III)-, and beta(IV)tubulin isotypes in paclitaxel-resistant MCF-7 breast cancer cells. Biochem Biophys Res Commun 2002, 293:598-601.

22. Wiesen KM, Xia S, Yang CP, Horwitz SB: Wild-type class I beta-tubulin sensitizes Taxol-resistant breast adenocarcinoma cells harboring a beta-tubulin mutation. Cancer Lett 2007, 257:227-235.

23. Iseri OD, Kars MD, Gunduz U: Drug Resistant MCF-7 cells have altered expression levels of beta-tubulin isotypes and mutations in TUBB gene. Int J Hematol Oncol 2010, 2:75-83.

24. Chien AJ, Moasser MM: Cellular mechanisms of resistance to anthracyclines and taxanes in cancer: intrinsic and acquired. Semin Oncol 2008, 35:S1-S14.

25. Hembruff SL, Laberge ML, Villeneuve DJ, Guo B, Veitch Z, Cecchetto M, Parissenti AM: Role of drug transporters and drug accumulation in the temporal acquisition of drug resistance. BMC Cancer 2008, 8:318.

26. Liu L, Shi H, Chen X, Wang Z: Regulation of EGF-stimulated EGF receptor endocytosis during M phase. Traffic 2011, 12:201-217.

27. Iseri OD, Kars MD, Eroglu S, Gunduz U: Drug Resistant MCF-7 cell lines also developed cross-resistance to structurally unrelated anticancer agents. Int J Hematol Oncol 2009, 19:1-8.

28. Smith NZ: Treating metastatic breast cancer with systemic chemotherapies: current trends and future perspectives. Clin J Oncol Nurs 2012, 16:E33-E43.

29. Kars MD, Iseri OD, Gunduz U, Ural AU, Arpaci F, Molnar J: Development of rational in vitro models for drug resistance in breast cancer and modulation of MDR by selected compounds. Anticancer Res 2006, 26:4559-4568.

30. Janicke RU, Sprengart ML, Wati MR, Porter AG: Caspase-3 is required for DNA fragmentation and morphological changes associated with apoptosis. J Biol Chem 1998, 273:9357-9360.

31. Kurokawa H, Nishio K, Fukumoto H, Tomonari A, Suzuki T, Saijo N: Alteration of caspase-3 (CPP32/Yama/apopain) in wild-type MCF-7, breast cancer cells. Oncol Rep 1999, 6:33-37.

32. Liang Y, Yan C, Schor NF: Apoptosis in the absence of caspase 3 Oncogene 2001, 20:6570-6578.

33. Mc Gee MM, Hyland E, Campiani G, Ramunno A, Nacci V, Zisterer DM: Caspase- 3 is not essential for DNA fragmentation in MCF-7 cells during apoptosis induced by the pyrrolo-1,5-benzoxazepine, PBOX-6. FEBS Lett 2002, 515:66-70.

34. Simstein R, Burow M, Parker A, Weldon C, Beckman B: Apoptosis, chemoresistance, and breast cancer: insights from the MCF-7 cell model system. Exp Biol Med (Maywood) 2003, 228:995-1003.

35. Malki A, Bergmeier SC: Novel quinuclidinone derivative 8a induced apoptosis in human MCF-7 breast cancer cell lines. Anticancer Res 2011, 31:871-880.

36. Patil JB, Kim J, Jayaprakasha GK: Berberine induces apoptosis in breast cancer cells (MCF-7) through mitochondrial-dependent pathway. Eur J Pharmacol 2010, 645:70-78.

37. Yeung KTGCCXWZ: The mode of action of taxol: apoptosis at low concentration and necrosis at high concentration. Biochem Biophys Res Commun 1999, 263:398-404.

38. Abal M, Andreu JM, Barasoain I: Taxanes: microtubule and centrosome targets, and cell cycle dependent mechanisms of action. Curr Cancer Drug Targets 2003, 3:193-203. 
39. Iseri $\mathrm{OD}$, Kars MD, Arpaci F, Gunduz U: Gene expression analysis of drugresistant MCF-7 cells: implications for relation to extracellular matrix proteins. Cancer Chemother Pharmacol 2010, 65:447-455.

40. Iseri OD, Kars MD, Gunduz U: Two different docetaxel resistant MCF-7 sublines exhibited different gene expression pattern. Mol Biol Rep 2012, 39:3505-3516.

doi:10.1186/1471-2407-14-37

Cite this article as: Wang et al: Multiple mechanisms underlying

acquired resistance to taxanes in selected docetaxel-resistant MCF-7

breast cancer cells. BMC Cancer 2014 14:37.

\section{Submit your next manuscript to BioMed Central and take full advantage of:}

- Convenient online submission

- Thorough peer review

- No space constraints or color figure charges

- Immediate publication on acceptance

- Inclusion in PubMed, CAS, Scopus and Google Scholar

- Research which is freely available for redistribution 